\title{
COMBINED SURGICAL APPROACH IN THE TREATMENT OF OCULO- ORBITAL COMPLICATIONS OF FRONTAL SINUS MUCOCELE: \\ A CASE REPORT
}

Andra Jevtovic ${ }^{1,2}$, Branislav Belic ${ }^{1,2}$, Jasmina Stojanovic ${ }^{2}$

${ }^{1}$ University of Kragujevac, Department of Otorhinolaryngology, Faculty of Medical Sciences, Kragujevac, Serbia

${ }^{2}$ Clinic of Otorhinolaryngology, Clinical Center Kragujevac, Kragujevac, Serbia

\author{
KOMBINOVANI HIRURŠKI PRISTUP U LEČENJU OKULO-ORBITALNIH \\ KOMPLIKACIJA MUKOKELE ČEONOG SINUSA: \\ PRIIKAZ SLUČAJA \\ Andra Jevtović1, ${ }^{2}$, Branislav Belić1,2, Jasmina Stojanović2 \\ ${ }^{1}$ Univerzitet u Kragujevcu, Fakultet medicinskih nauka, Katedra za otorinolaringologiju, Kragujevac, Srbija \\ ${ }^{2}$ Klinika za otorinolaringologiju, Klinički centar Kragujevac, Kragujevac, Srbija
}

\begin{abstract}
Paranasal sinus mucoceles are benign cystic masses filled with mucous content. Mucoceles are locally destructive, causing pressure on sinus walls with their resorption, allowing them to spread on adjacent structures causing local, orbital or intracranial complications. They are most commonly found in frontal sinuses.

The aim of this report is to present case of oculo-orbital complications of frontal sinus mucocele, with focus on treatment using combined surgical approach.

A 75-year old female patient with frontal sinus mucocele which led to destruction of orbital roof and occurrence of complications in form of orbital cellulitis and palpebral abscess was successfully treated with a combination of external frontoethmoidectomy and endoscopic sinus surgery. After initial incision of the upper eyelid abscess with drainage of purulent content, modified external frontoethmoidectomy was performed using preformed defect of orbital roof. Finally, using endoscopic sinus surgery, natural drainage of anterior group of paranasal sinuses was achieved.

Various endoscopic and open approaches have been described in mucocele treatment. In this case we showed that the combined surgical approach in the treatment of frontal sinus mucoceles with destruction of sinus floor and appearance of oculoorbital complications, provides an effective treatment and allows natural drainage of anterior group of sinuses.
\end{abstract}

Keywords: Paranasal sinuses, mucoceles, oculo-orbital complications.

\section{SAŽETAK}

Mukokele paranazalnih šupljina su benigne cistične tvorevine ispunjene mukoznim sadržajem. Mukokele su lokalno destruktivne, tako što pritiskom na zid sinusa uzrokuju njegovu resporpciju, što im omogućava da se šire na okolne strukture i izazovu lokalne, orbitalne i intrakranijalne komplikacije. Najčešće su lokalizovane u čeonim sinusima.

Cilj ovog rada je prikaz slučaja okulo-orbitalnih komplikacija mukokele čeonog sinusa, sa akcentom na lečenje kombinovanim hirurškim pristupom.

Pacijentkinja starosti 75 godina, sa mukokelom čeonog sinusa koja je dovela do destrukcije krova orbite i pojave komplikacija u formi orbitalnog celulitisa i palpebralnog abscesa, je uspešno lečena kombinacijom spoljne frontoetmoidektomije $i$ endoskopske hirurgije sinusa. Nakon inicijalne incizije abscesa gornjeg očnog kapka sa drenažom purulentnog sadržaja, izvedena je modifikovana spoljna frontoetmoidektomija kroz preformirani koštani defekt krova orbite. Na kraju, endoskopskom hirurgijom sinusa omogućena je prirodna drenaža prednje grupe paranazalnih sinusa.

Različite endoskopske i otvorene hirurške tehnike su opisane u terapiji mukokela. U ovom slučaju smo pokazali da kombinovani hirurški pristup u lečenju mukokela čeonog sinusa sa destrukcijom poda čeonog sinusa i pojavom okulo-orbitalnih komplikacija, omogućava efikasan tretman i prirodnu drenažu prednje grupe sinusa.

Ključne reči: Paranazalne šupljine, mukokele, okulo-orbitalne komplikacije.

\section{ABBREVIATIONS:}

ESS - Endoscopic sinus surgery

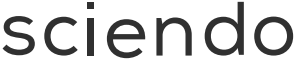

UDK: 616.216-003.4-089

Ser J Exp Clin Res 2021; 22 (2): 175-180

DOI: $10.2478 /$ sjecr-2018-0072

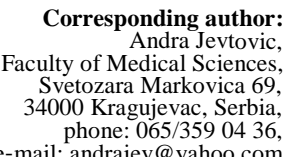

Corresponding author: Faculty of Medical Sciences, 34000 Kragujevac, Serbia, e-mail: andrajev@yahoo.com 


\section{INTRODUCTION}

Paranasal sinus mucoceles are slow-growing, cubic or pseudostratified epithelium-lined, mucous filled, cystic masses, usually resulting from obstruction of sinus ostia, that are locally destructive, causing bony resorption and displacement of adjacent structures $(1,2,3)$. The occlusion of the ostia may be secondary to anatomic abnormalities, infection, allergy, trauma, tumours or sinus operations $(3,4,5)$. It has also been suggested that a cystic degeneration of a goblet cell gland could result in a mucocele (4). The most commonly affected is the frontal sinus, followed by the ethmoid sinuses, with reports suggesting $70-90 \%$ of mucoceles occur in these locations (1). Ten percent of mucoceles occur in the maxillary sinus while the sphenoid sinus is rarely affected (1). The clinical presentation of mucoceles varies with their anatomical site (5). The onset of symptoms is usually insidious, and intensification of symptoms usually indicate development of complications $(3,5)$. Patients may be referred with symptoms of varying severity according to the lesion location, size of the bone defect, and symptoms due to compression (3). Patients with frontoethmoidal mucoceles may develop frontal headache, facial asymmetry, or swelling, as well as ophthalmological manifestations, such as impaired visual acuity, reduced ocular mobility or proptosis $(1,5)$. Beside anamnesis, clinical examination and nasal endoscopy, the diagnosis is based on computed tomography (CT) and magnetic resonance imaging (MRI) (6). CT and MRI of the sinuses allow the assessment of mucocele extension in relation to adjacent structures (6).

Surgery is the only method of treating paranasal sinus mucoceles (6). Considerations in the surgical approach for dysfunctional frontal sinuses include obliteration of affected sinus or restoring ventilation to the sinus through reestablishing the natural frontal sinus outflow tract (7). Initially, mucoceles were treated mainly by extirpation using external approaches and sinus obliteration to avoid recurrence (8). With introduction of endoscopic sinus surgery (ESS), mucocele marsupialization and enabling of sinus drainage became a valid choice for the treatment of selected types of mucoceles $(8,9)$.

In this paper we showed that the combined surgical approach provides an effective method in the management of a frontal sinus mucoceles involving the orbit. Since mucocele exteriorisation towards orbit led to sinus floor destruction, sinus obliteration was possible only through radical sinus surgery, such as Riedel procedure, that would lead to aesthetic impairment. Through already formed orbital roof defect, we were able to completely remove mucocele using modified frontoethmoidectomy, while ESS allowed us to enable drainage of the frontal sinus and ethmoid cells, thus sinus obliteration was not necessary.

\section{CASE REPORT}

A seventy five year old female patient with the swelling of left upper eyelid was admitted to Otorhinolaryngology Clinic, Clinical Center Kragujevac, Serbia, for additional radiographic diagnostics including multislice computed tomography (MSCT) of paranasal sinuses and left orbit and treatment, on account of suspected oculo-orbital complication of sinusitis. Anamnestic data showed that patient suffered sinusitis a month before, and that the left upper eyelid swelling started 3 weeks ago. Conservative therapy prescribed by otorhinolaryngologists and ophtalmologists did not give significant result. A clinical exam on admission showed intumescence, redness and ptosis of left upper eyelid, which resulted in completely closing the left orbit (Figure 1). In the central part of intumescence there was $10 \times 10 \mathrm{~mm}$ solid tumefaction, painful on palpation, indicating that palpebral abscess was formed. Eye bulb was compressed to the lower part of the orbit, with the patient suffering from diplopia. With nasal endoscopy we observed bilateral hiperemy and oedema of nasal mucosa with purulent secretion.

Figure 1. Preoperative local findings

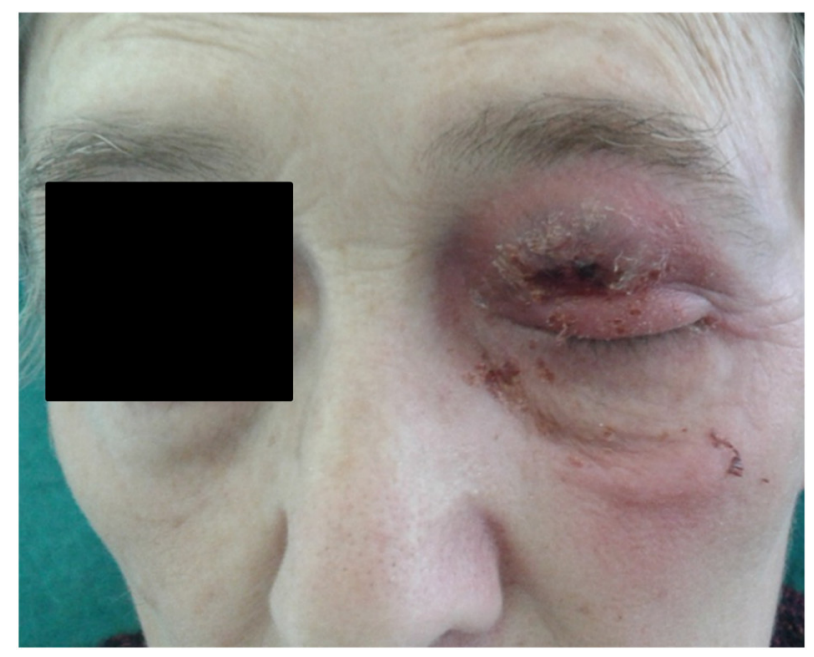

MSCT pointed out intumescence with central hypodense zone in the region of left upper eyelid and subcutaneously in the region of frontal bone arc, which spreads into medial part of the orbit (Figure 2A, B). There was a bone defect of the orbital roof, together with the spreading of the frontal sinus content towards the orbit, which was liquid to viscous secretion attenuation, without clear radiography signs of continuity with described intumescence of left upper eyelid (Figure $2 \mathrm{C}, \mathrm{D})$. MSCT findings of other paranasal sinuses indicated that the patient suffered from pansinusitis. Microbiological analysis of the left upper eyelid material showed S.aureus infection. All examinations suggested that the patient suffered from pansinusitis with secondary infected mucocele of left frontal sinus (pyocele) with oculo-orbital complication in form of cellulitis and palpebral abscess. 
After adequate preoperative preparation, which included preanesthetic assessment, internistic and ophtalmic examination as well as laboratory diagnostics, we performed a surgical treatment. Initially we made incision of the left upper eyelid abscess with drainage of purulent content. Then, we performed modified external frontoethmoidectomy using preformed defect of orbital roof, with extirpation of the left frontal sinus mucocele (Figure 3).
Finally, we carried out ESS of the left side of the nose including infundibulectomy, medial meatotomy and anterior ethmoidectomy enabling natural drainage of anterior group of sinuses. Histopathological analysis of inflammatory altered left frontal sinus mucosa confirmed clinical diagnosis. The patient was discharged from the hospital on $9^{\text {th }}$ postoperative day, without complications and signs of recurrence on follow up examinations.

Figure 2. MSCT findings pointing out the presence of palpebral abscess on transfersal (A) and sagittal (B) section. Frontal sections showing bone defect of orbital roof with spreading of the frontal sinus content towards the orbit on the soft tissue (C) and bone (D) CT window

A)

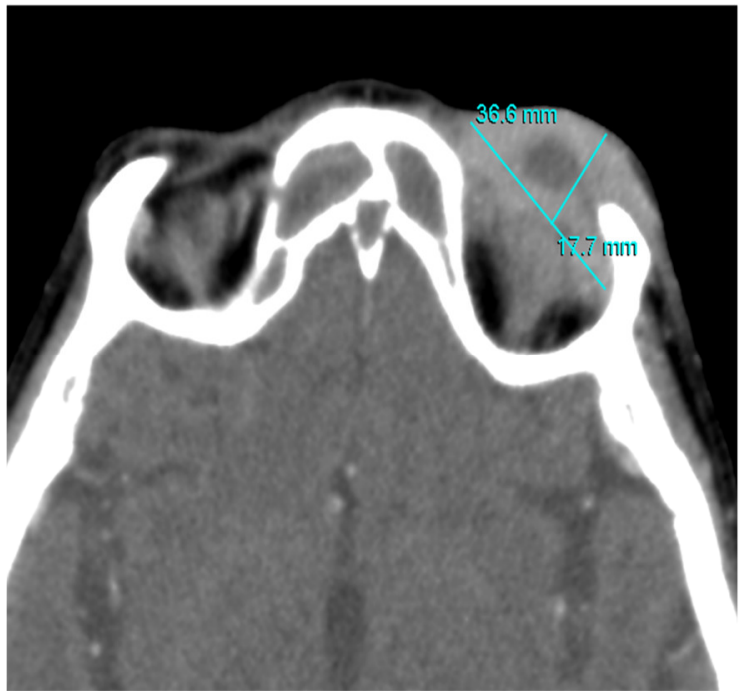

C)

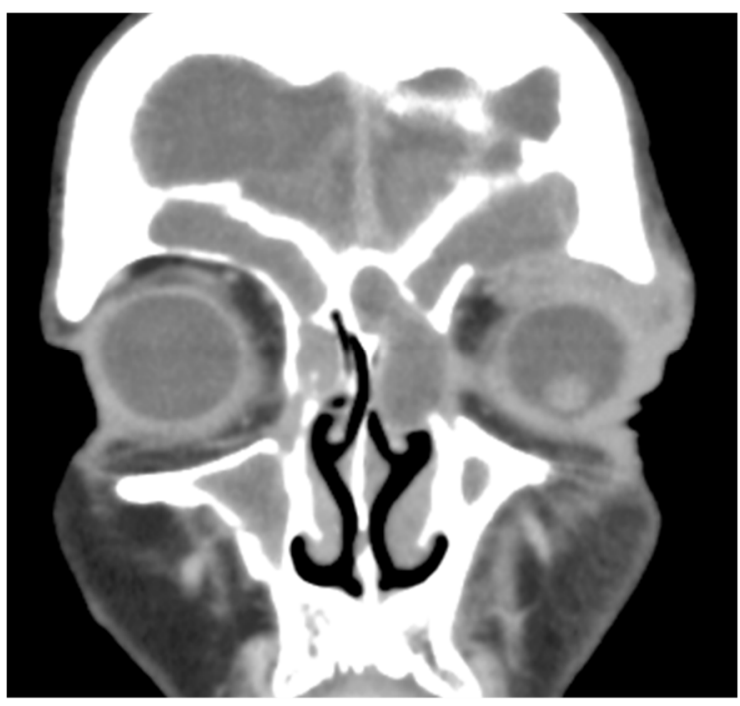

B)

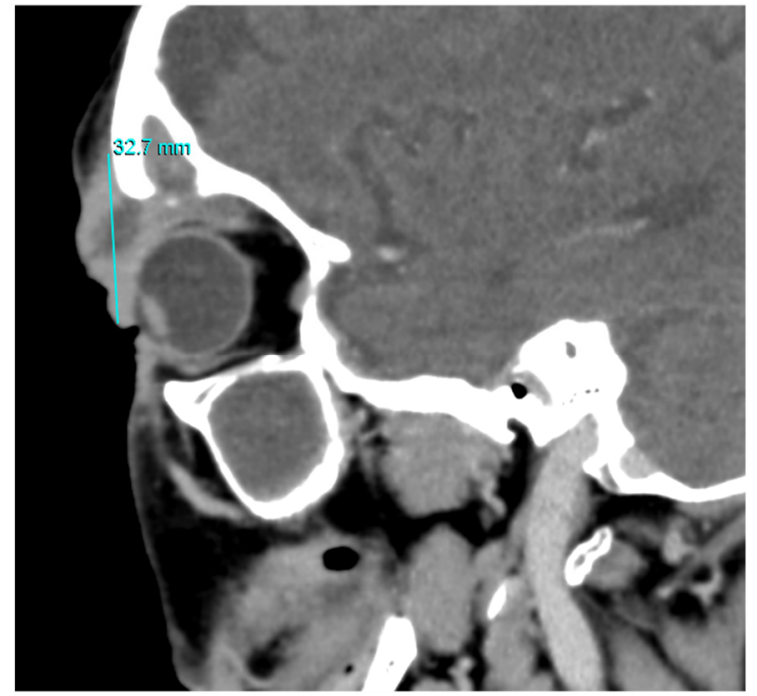

D)

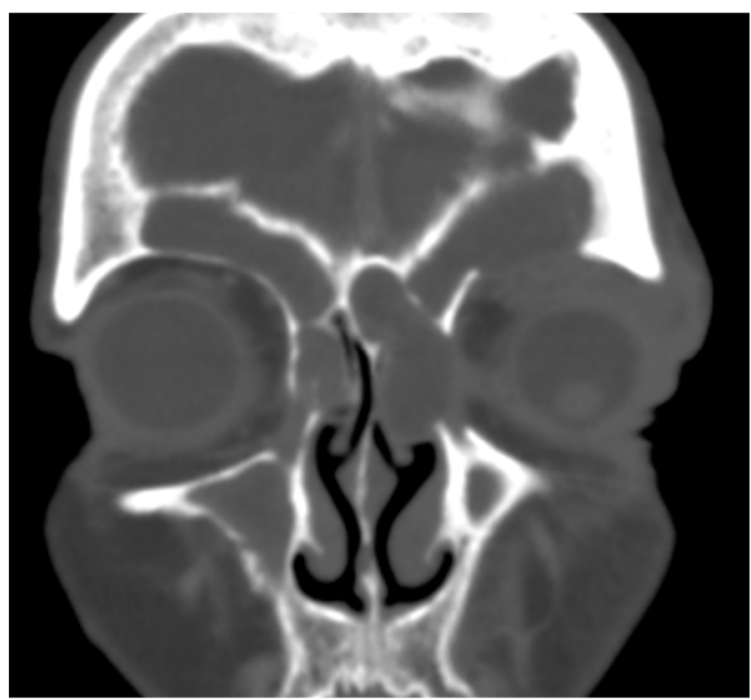


Figure 3. Intraoperative findings while performing modified external frontoethmoidectomy
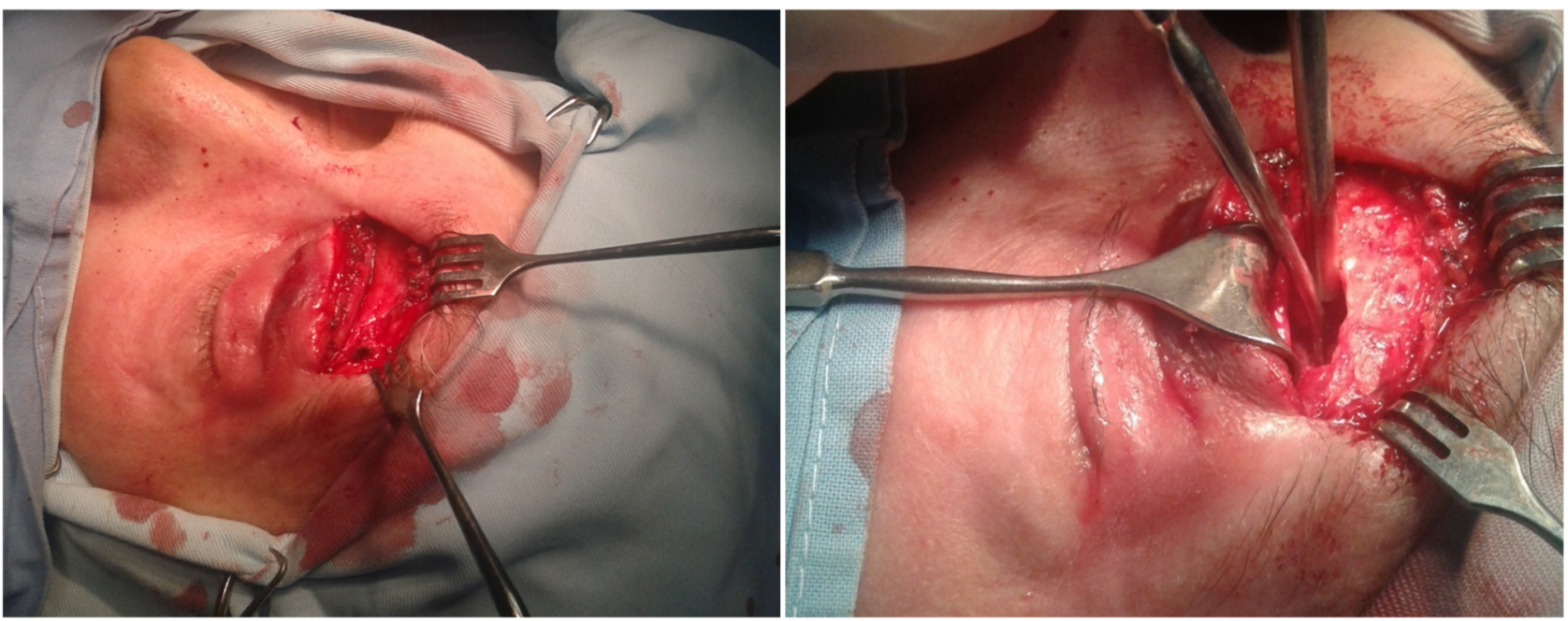

\section{DISCUSSION}

Mucoceles are epithelium-lined mucous filled cystic formations which usually develop when the ostium of paranasal sinus became obstructed (10). They most commonly occur in the third or fourth decades of life with a slight male predilection (1). The mucoceles are benign, slow-growing lesions that commonly occur in the frontal or ethmoidal group of sinuses (5). In the period from 2006-2017 we had 16 cases of mucoceles in our Clinics, $9(56.25 \%)$ of those primarily localised in frontal sinuses, $4(25 \%)$ in ethmoids and 3 $(18.75 \%)$ in maxillary sinuses, with no cases of sphenoid sinus mucocele. Symptoms usually develop slowly, and their intensification indicates occurrence of complications (5). Mucocele complications can be local, orbital and intracranial and they appear as a consequence of bone destruction and secondary mucocele infection (pyocele) $(2,11)$. Bone degradation is caused by increased size of mucocele, continuous augmentation of pressure on sinus walls, and the release of inflammatory mediators such as prostaglandin E2 and collagenase at the capsule of the mucocele, which degrades the bone (12). Patients may be referred with symptoms of varying severity according to the lesion location, size of the bone defect, and symptoms due to compression (3).

The most common symptoms of patients with frontoethmoid sinus mucoceles are headache, swelling or facial asymmetry and ophthalmic symptoms, such as visual disturbance, proptosis and diplopia (13). In the case of local complication, frontoethmoid mucoceles are often associated with a palpable mass in the superonasal and medial canthal region (14). Destruction of the posterior frontal sinus wall results in intracranial mucocele complication which can be presented as meningitis, meningoencephalitis, brain abscess, seizures, or cerebrospinal fluid fistula (11). Unilateral proptosis is the most common presenting sign of an oculo-orbital frontal mucocele complication, as in our case $(15,16)$. Other ophthalmic symptoms include outward and downward displacement of the globe, restriction of eye movements, diplopia, visual loss, retroorbital pain or headache (17). In our case, proptosis was associated with upper eyelid hyperemia and oedema, conjunctival chemosis, downward displacement of the globe and diplopia. Since the swelling of the upper eyelid was the main presenting feature, this condition could have been easily misdiagnosed and treated inappropriately. However, the red flags that should be pointed out in our cases were the unresponsiveness to the treatment, a palpable well-circumscribed mass in the upper palpebral region and clinical signs of sinusitis. Most common nasal symptoms such as nasal blockage and secretion, as well as loss of sense of smell can be signs of nasal expansion of mucocele, or sinusitis as in our case (18).

The diagnosis of the mucocele is based on anamnesis, clinical examination, nasal endoscopy with the aid of CT and MRI (14). CT provides information about regional anatomy, degree of bone destruction and lesion extension $(1,14)$. Mucoceles are typically presented on CT as homogenous, isodense masses, with clearly defined margins surrounded by osteolyitic sinus wall lesions (10). MR imaging is useful in differentiating mucoceles from neoplasms and surrounding soft tissue in cases of their expansions, using contrast enhancement $(1,14)$. Dermoid cysts, histiocytosis, fungal and tuberculosis infections, fronto-orbital cholesterol granuloma, and neoplasms must be considered in the differential diagnosis (5). In our case, we based our diagnosis on clinical examination, nasal endoscopy and MSCT. Examination indicated the presence of the left upper eyelid abscess, with left orbit cellulitis causing proptosis and diplopia. Nasal endoscopy examination showed signs of chronic rhinosinusitis exacerbation presented as bilateral nasal mucosa hyperemia and oedema with purulent secretion originating from the middle nasal meatus. MSCT imaging provided us with the information about superior orbital wall lesion with extension of clearly demarcated cystic formation towards left orbit and confirmed 
clinical diagnosis of orbital cellulitis, palpebral abscess and pansinusitis.

Until the late 80s, paranasal sinus mucoceles were treated with open surgical procedures such as frontal sinus osteoplasty, external frontoethmoidectomy and maxillary sinus trepanation $(1,8)$. Traditional teaching emphasized the need for a complete removal of the sinus mucocele lining and obliteration of the sinus to avoid recurrence (8). Management of mucocele has significantly changed since the introduction of ESS, so that mucocele marsupialization and enabling of sinus drainage became a valid choice for the treatment of selected types of mucoceles $(8,9)$.

Kennedy et al. marsupialized 9 of 11 frontal mucoceles and reported no cases of relapse, and Har-El marsupialized endoscopically 108 paranasal sinus mucoceles including 66 frontal and frontoethmoid, 17 ethmoid, 7 sphenoethmoid, 12 sphenoid, and 6 maxillary mucoceles with recurrence of a frontal mucocele seen in 1 patient $(0.9 \%)(19,20)$. Lund treated 48 mucoceles in the frontal, frontoethmoidal and sphenoidal sinuses during the period of five years, 20 by an entirely endonasal endoscopic approach and 28 by a combination of an external procedure and an endoscopic approach (21). Nevertheless, most of the authors agree that even though ESS is nowadays the surgical method of choice, the treatment of mucocele depends on many factors (5).

The location, magnitude, and expansion of the lesion are main determinants of the appropriate surgical procedure (3). Many authors consider lateral localization of frontal mucocele a contraindication to ESS (22). Martel-Martin et al. indicate an external approach for frontal mucoceles which only affect the most external and posterosuperior region of the sinus, when the appearance of the mucocele is the consequence of an endosinusal process which septates the sinus, such as an osteoma or major sclerosis in the region of the frontal recess (2). On the other hand, Sharouny et al. suggest that endoscopic sinus surgery is the treatment of choice in most cases of frontal sinus mucoceles including lateral frontal mucoceles (23). While smaller lesions can be treated endoscopically, larger lesions can usually be managed only via external procedures and sinus obliteration to prevent the ascending infections (14). Trimarchi et al. suggest that it is essential to determine mucocele extension beyond a virtual sagittal plane tangential to the medial side of the ocular globe and consider mucocele extension medially to the virtual sagittal plane as the main selection criterion for ESS, more important than the size of the mucocele (8). Endoscopic trans-sinusal approach is not recommended in cases of intracranial extension of mucocele because of the higher risk of intracavitary residual and postoperative recurrences due to a narrow access to the lesion (24). On the other hand, obliteration of the involved sinus is not recommended if there is an erosion of the sinus bony wall with extension of the mucocele into the orbit, because mucosa lining the mucocele becomes adherent to orbital periosteum and cannot be removed during the surgery without significant risk of injury to the adjacent structures (9). And, if mucosa is left behind and the sinus obliterated, a recurrence of the mucocele is highly likely (9). As most cases of symptomatic mucocele have erosion of the bony sinus wall, the obliteration of the sinus should not be considered (9). Kim et al. note that minimally invasive surgery to remove ethmoid mucoceles with orbital complications is relatively straightforward and avoids the complications associated with these lesions (13). In cases where intranasal treatment presents difficulties, it is possible to use an external route or a combined approach with external treatment under endoscopic control (5). Beigi et al. suggest that the combined internal/external approach provides a viable and effective method for managing frontal sinus mucocele involving the orbit (25).

In our Clinics, in the period from 2006-2017 we treated $3 / 9(33.3 \%)$ frontal sinus mucocele endoscopically, while for the 6/9 $(66.7 \%)$ we decided to use external approach. In the case of ethmoid sinus mucocele we used ESS in $4 / 4(100 \%)$ cases, while $2 / 3(66.7 \%)$ mucoceles were treated endoscopically and recurrent $1 / 3(33.3 \%)$ with the open technique. We suggest that in any case of asymptomatic mucocele, as well in the cases without exteriorisation of mucocele, ESS with mucocele marsupialization and allowing sinus drainage should be performed. If mucocele is inaccessible, recurrent or complications occurred, we recommend using an adequate external or combined surgical approach. In this case, since oculo-orbital complication occurred, we decided for a combined surgery. External frontoethmoidectomy allowed us to completely remove mucocele through already formed orbital roof defect. Endoscopically we managed to enable drainage of the frontal sinus and ethmoid cells, thus sinus obliteration through radical sinus surgery that would lead to aesthetic impairment was not necessary.

\section{CONCLUSION}

Because of the tendency to destruct sinus wall, mucoceles can cause complications at some point. To prevent complications, early diagnosis and timely surgical treatment is necessary. Endoscopic sinus surgery and marsupialization should be the treatment of choice for asymptomatic and simple frontal mucoceles. More radical approaches are required if the size of mucoceles is large and if there appears to be extensive bone erosion causing orbital or intracranial complications. We believe that obliterative sinus surgery should be avoided whenever possible and reserved mostly for the cases of intracranial complications in order to avoid spreading the ascending infection, since obliteration of sinus ostia by itself can be cause of mucocele recurrence. Postoperative longterm follow-up with endoscopic surveillance is mandatory for every patient because recurrence of mucocele could occur many years after surgical management. 


\section{REFERENCES}

1. Capra GG, Carbone PN, Mullin DP. Paranasal sinus mucocele. Head Neck Pathol. 2012;6(3):369-72.

2. Martel-Martin M, Gras-Cabrerizo JR, Bothe-Gonzalez C, Montserrat-Gili JR, De Juan-Delago M, MassegurSolench H. Clinical analysis and surgical results of 58 paranasal sinus mucoceles. ActaOtorrinolaringol Esp. 2015;66(2):92-7.

3. Topdag M, Iseri M, Sari F, Erdogan S, Keskin IG. Paranasal sinus mucoceles: our clinical experiments. Int $\mathrm{J}$ ClinExp Med. 2015;8(10):18518-22.

4. Rajan KV, Santhi T. Frontoethmoidal mucocele with orbital and intracranial extension. Indian J Otolaryngol Head Neck Surg. 2007;59(4):363-5.

5. Aggarwal SK, Bhavana K, Keshri A, Kumar R, Srivastava A. Frontal sinus mucocele with orbital complications: Management by varied surgical approaches. Asian J Neurosurg. 2012;7(3):135-40.

6. Devars du Mayne M, Moya-Plana A, Malinvaud D, Laccourreye O, Bonfils P. Sinus mucocele: natural history and long-term recurrence rate. Eur Ann Otorhinolaryngol Head Neck Dis. 2012;129(3):125-30.

7. Schlosser RJ. Surgical salvage for the non-functioning sinus. Otolaryngol Clin North Am. 2010;43(3):591-04.

8. Trimarchi M, Bertazzoni G, Bussi M. Endoscopic treatment of frontal sinus mucoceles with lateral extension. Indian J Otolaryngol Head Neck Surg. 2013;65(2):15156.

9. Khong JJ, Malhotra R, Wormald PJ, Selva D. Endoscopic sinus surgery for paranasal sinus mucocoele with orbital involvement. Eye (Lond). 2004;18(9):877-81.

10. Tan CS, Yong VK, Yip LW, Amrith S. An unusual presentation of a giant frontal sinus mucocele manifesting with a subcutaneous forehead mass. Ann Acad Med Singapore. 2005;34(5):397-8.

11. Suri A, Mahapatra AK, Gaikwad S, Sarkar C. Giant mucoceles of the frontal sinus: a series and review. J ClinNeurosci. 2004;11(2):214-8.

12. Lajmi H, Hmaied W, Ben Jalel W, Ben Romdhane K, Chelly Z, El Fekih L. Unilateral proptosis revealing a fronto-ethmoidal mucocele. Tunis Med. 2017;95(6): 449-51.
13. Kim JS, Kim EJ, Kwon SH. An ethmoid mucocele causing diplopia: A case report. Medicine (Baltimore). 2017;96(50):e9353.

14. Bijith EV, Mathew S, Mahadevan K. Frontal mucocele mimicking a frontal subcutaneous tumor. Asian J Neurosurg. 2017;12(4):760-62.

15. Peral Cagigal B, Barrientos Lezcano J, Floriano Blanco R, Garcia Cantera JM, Sanchez Cuellar LA, Verrier Hernandez A. Frontal sinus mucocele with intracranial and intraorbital extension. Med Oral Patol Oral Cir Bucal. 2006;11(6):E527-30.

16. James E, Dutta A, Swami H, Ramakrishnan R. Frontal mucocele causing unilateral proptosis. Med J Armed Forces India. 2009;65(1):73-4.

17. Aydin E, Akkuzu G, Akkuzu B, Bilezikci B. Frontal mucocele with an accompanying orbital abscess mimicking a fronto-orbital mucocele: case report. BMC Ear Nose Throat Disord. 2006;6:6.

18. Mohan S. Frontal sinus mucocele with intracranial and intraorbital extension: a case report. J Maxillofac Oral Surg. 2012;11(3):337-9.

19. Kennedy DW, Josephson JS, Zinreich SJ, Mattox DE, Goldsmith MM. Endoscopic sinus surgery for mucoceles: a viable alternative. Laryngoscope. 1989;99(9):885-95.

20. Har-El G. Endoscopic management of 108 sinus mucoceles. Laryngoscope. 2001;111(12):2131-4.

21. Lund VJ. Endoscopic management of paranasal sinus mucocoeles. J Laryngol Otol. 1998;112(1):36-40.

22. Chiu AG, Vaughan WC. Management of the lateral frontal sinus lesion and the supraorbital cell mucocele. Am J Rhinol. 2004;18(2):83-86.

23. Sharouny H, Narayanan P. Endoscopic marsupialisation of the lateral frontal sinus mucocele with orbital extension: a case report. Iran Red Crescent Med J. 2015;17(1):e17104.

24. Severino R, Severino P. Fronto-orbital mucocele with intracranial extension: a case report. J Surg Case Rep. 2017;6:1-3.

25. Beigi B, Vayalambrone D, Kashkouli MB, Prinsley $\mathrm{P}$, Saada J. Combined external and endonasal approach to fronto-ethmoidal mucocele involving the orbit. J CurrOphthalmol. 2016;28(1):37-42. 